\title{
The Evolution and International Comparison of China's Industrial Products Export Diversification Sheng-lan Huang ${ }^{a^{*}}$, Yun-fei Chen ${ }^{b}$ \\ a Jiangxi Normal University, China \\ ${ }^{\mathrm{b}}$ Party School of the Jiangxi Provincial Committee of CPC, China \\ *Corresponding author: Sheng-lan Huang, Lecturer, hslan@126.com
}

\begin{abstract}
This paper analyzes China's industrial products export diversification from the level of country in 1992 - 2012 and makes international comparisons by using theil index which is used for measuring export concentration, and it discusses the evolution of export diversification dual margin of China's industrial products. The research shows that China's industrial products export diversification level is high when compared with the sample countries. China should encourage technological innovation to promote the development of China's industrial products export diversification extensive margin, and enhance its export diversification intensive margin, and realize coordinated development of China's industrial products export diversification dual margin.
\end{abstract}

Key words: industrial products; export diversification; extensive margin; intensive margin; international comparison

\section{Introduction}

In the past, China obtained the rapid development of export trade with the comparative advantage of labour force. Many scholars raised a hot wave of research on China's export trade growth. Qian et al.(2010) ${ }^{1}$, Yi et al.(2013) ${ }^{2}$ analyzed export growth dual margin by heterogeneous enterprise trade theory of Melitz (2003) ${ }^{3}$. They pointed out that China's export trade expanding mainly attributed to intensive margin and China's exports were highly susceptible to the influence of external economic shocks. Some scholars analyzed the issues of China's export products diversification development pattern. Some scholars used export products diversification index based on Feensntra(1994) $)^{4}$ to measure China's export products diversification, such as $\mathrm{Xu}(2009)^{5}$, Feenstra and $\mathrm{Kee}(2007)^{6}$. Some scholars used export concentration index to analyze China's export diversification at state level, but they had not got unified conclusion on the development pattern of China's export products diversification. Considering a country's export products diversification level mainly reflects on the diversification of industrial products, this paper uses theil index which can be used to measure export concentration to analyze China's industrial products export diversification development level. And according to decomposition method of theil index by Cadot et al.(2011) ${ }^{7}$, we can explore extensive and intensive margin of China's industrial products export diversification. It can help us to learn more about China's export products diversification. 


\section{Method of export products diversification and data instructions}

\subsection{Method of export product diversification}

Scholars usually choose export concentration index to measure export products diversification, such as gini index, theil index and herfindal index. These indexes have a relationship with the number and proportion distribution of export products. When the kinds of export products are much more and the proportion distribution of export products is much even, the export products concentration index will be smaller, and export products diversification level will be higher. Instead, when these indexes are big, the export products diversification level is low.

Theil index is also called theil entropy criteria, many scholars use this index to measure export products concentration. Because entropy index has decomposition characteristic, Cadot et al.(2011) decomposed theil index into within and between theil index which respectively corresponding to the intensive margin and extensive margin. Obviously, using theil index to measure export products diversification and using the decomposition method of theil by Cadot et al.(2011), we can describe the evolution of export products diversification from extensive margin and intensive margin.

According to theil index, we can use Eq.(1) to measure a country's export products diversification .

$$
\text { Theilc }=\frac{1}{\mathrm{n}} \sum_{\mathrm{k}=1}^{\mathrm{n}} \frac{\mathrm{x}_{\mathrm{kc}}}{\mu_{\mathrm{c}}} \ln \left(\frac{\mathrm{x}_{\mathrm{kc}}}{\mu_{\mathrm{c}}}\right)
$$

In Eq.(1), Theilc represents Theil index of country c' s export product, xkc represents export volume of product $\mathrm{k}$ in country $\mathrm{c}, \mu_{\mathrm{c}}$ represents average export volume of country $\mathrm{c}, \mathrm{n}$ represents the number of all potential kinds of export products. According to Cadot et al.(2011) we can make a decomposition of theil index and get within and between theil index of country c:

$$
\begin{aligned}
& \lim _{\mu_{0} \rightarrow 0} T_{c}^{B}=\ln \left(\frac{\mu_{1 c}}{\mu_{c}}\right)=\ln \left(\frac{n}{n_{1 c}}\right) \\
& \lim _{x_{0} \rightarrow 0} T_{c}^{W}=\frac{1}{n_{1 c}} \sum_{k \in G_{1 c}} \frac{x_{k c}}{\mu_{1 c}} \ln \left(\frac{x_{k c}}{\mu_{1 c}}\right)
\end{aligned}
$$

In Eq.(2) and Eq.(3), $\mathrm{T}_{\mathrm{c}}^{\mathrm{B}}$ represents between theil index of country c's export products, which reflects export diversification extensive margin of country c. $\mathrm{T}_{\mathrm{c}}^{\mathrm{W}}$ represents within theil index of country c's export products, which reflects export diversification intensive margin. $\mu_{1 \mathrm{c}}$ is the average export volume of frequent export products. $\mathrm{n}_{1 \mathrm{c}}$ is the number of frequent export products. $\mathrm{x}_{\mathrm{kc}}$ is product $\mathrm{k}$ 's export volume of country c.

According to the above definition, we can use theil index and its decomposition to measure a country's export products diversification and its dual margin.

\subsection{Data instructions}

This paper mainly analyzes the evolution of China's industrial products export diversification, and we choose 17 representative countries to make an international comparison. We want to master the status of China's industrial products export diversification in the world. Firstly, we choose SITC Rev.3 five-digit export products data of 17 countries in 1992-2012 from WITS. Then we gather SITC Rev.3 five-digit export data to three-digit. Finally, we build up the corresponding relationship between China's industrial industry and SITC Rev.3 three-digit according to Sheng $(2002)^{8}$, and we get the data of export industrial products at state level. According to the industry classification method of Sheng(2002), the number of all potential 
export industrial products is 4891. When we use Theil index to measure China's export industrial product, the value of $n$ is 4891 .

\section{The evolution of China's industrial products export diversification}

According to Eq. (1), we calculate theil index of China's export industrial producst, and we use this index to reflect China's industrial products export diversification , which is showed in Fig.1.

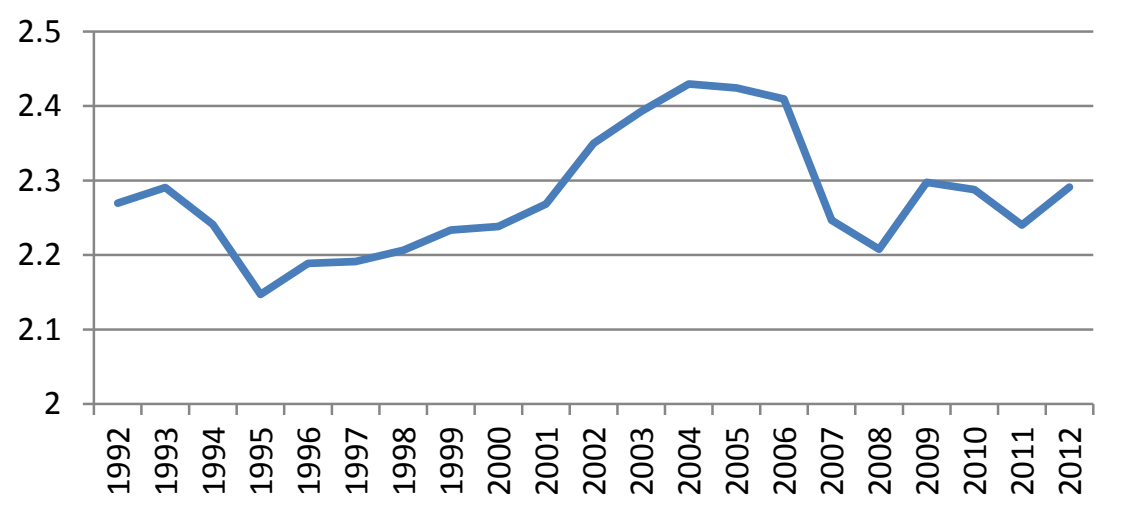

Fig.1 The evolution of China’s industrial products export theil index in 1992-2012

According to Eq.(2) and Eq.(3), we can get export between theil index and export within theil index of China's industrial products in 1992-2012, and we can analyze export diversification dual margin of China's industrial products which are showed in Fig. 2 and Fig.3.

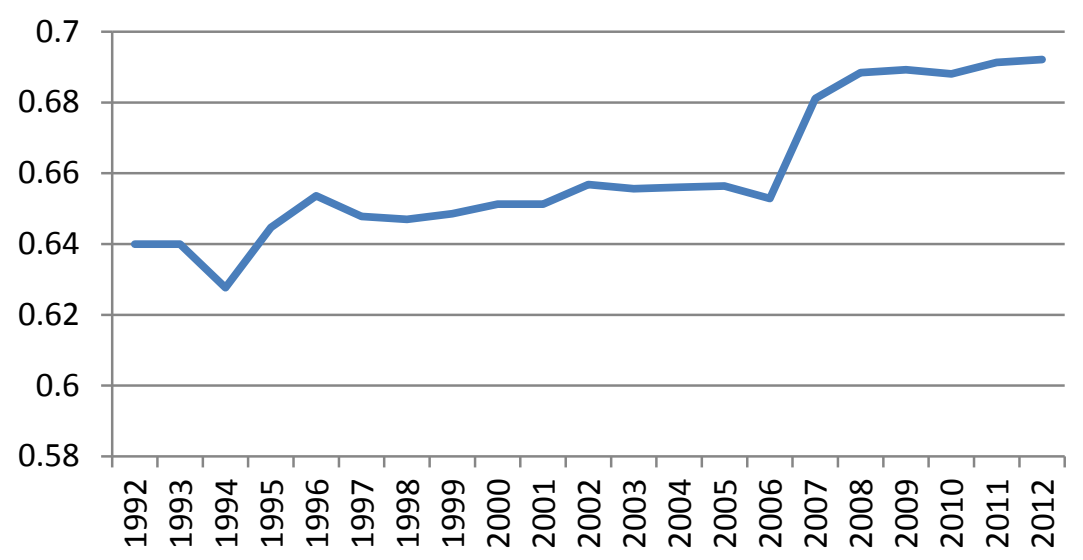

Fig.2 The evolution of China's industrial products export between theil index in 1992-2012

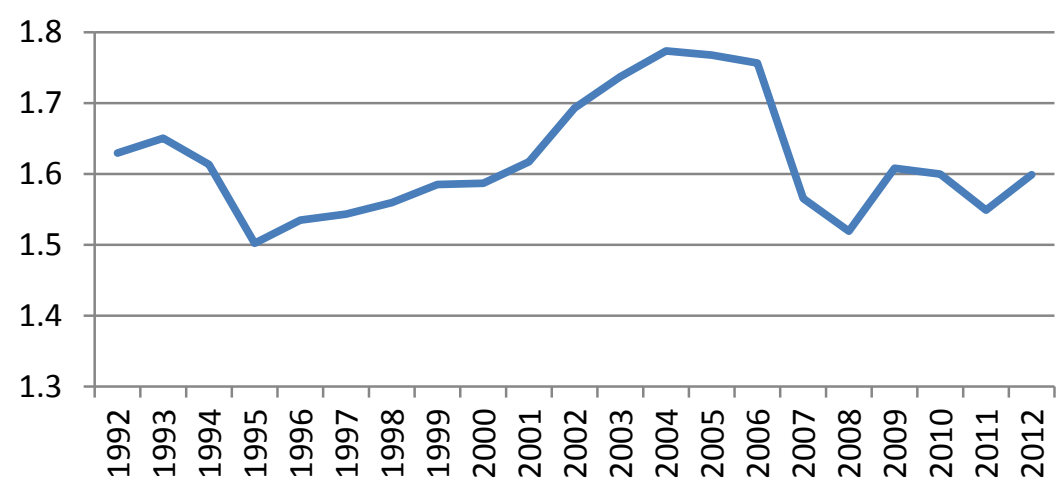

Fig.3 The evolution of China's industrial products export within theil index in 1992-2012 
From Fig.1, Fig.2 and Fig.3, we can find that China's industrial products export within theil index is the main part of export theil index, and China's industrial products export within theil index has similar trends with its export theil index. China's industrial products export within theil index shows a rising trend on the whole, and it has a major impact on the change of export theil index. According to Fig.1, we can divide the trend of China's industrial products export diversification into four stages. The first stage is from 1992 to 1995, this is deepening stage of export diversification. After Xiao-ping Deng made a speech in southern in 1992, China promoted its reform and opening up, and the kinds of export industrial products were obviously increasing. In Fig.2, export between theil index declined a little in 1994, which showed the signs of export diversification extensive margin increasing and the kinds of export products increasing. In Fig.2 and Fig.3, export within theil index decreased 6.9\% in 1995 and export between theil index increased $2.7 \%$, which showed that export diversification intensive margin increased more than extensive margin decreased in 1995, so export theil index of industrial products continued decreasing, and industrial products export diversification level continued increasing. We can see that China's industrial products showed obviously characteristics of export diversification in 1992-1995.

The second stage is from 1995 to 2004, and this is export diversification of deepening stage. In Fig. 2 and Fig.3, China's industrial products export within theil index shows the signs of obviously rising, but the change of industrial products export between theil index is not obvious, so Fig.1 also shows that China's industrial products export theil index keeps increasing in this stage, which reflects China's industrial products exports mainly increase in trade volume other than increase in the kinds of export product. So export diversification of China's industrial products decreases in this stage.

The third stage is from 2004 to 2008, and it is fluctuant stage of export diversification. Due to the influence of US subprime mortgage crisis in 2007, China's industrial products export within theil index declined fast in 2007 and 2008, but export between theil index increased significantly in 2007. This shows that the scale of China's industrial products export diversification appears atrophy. In this case China's industrial products export theil index decreases sharply, and its export diversification gets improved.

The fourth stage is from 2008 to 2012, it is an stable stage of export diversification. Fig. 1 shows that China's industrial products export theil index is stable during this period. China's industrial products export between theil index does not have a big change and the fluctuation of export within theil index is stable. So the change of China's industrial products export diversification is stable in this period.

\section{Comparison of China's industrial product export diversification}

Due to the limitation of the paper, we list 17 countries' industrial products export theil index and we rank these countries according to the index in 1992-2012, which is showed in Table 1. From Table 1, we can find that China's export diversification ranks ninth among 17 countries in 1992 and ranks sixth in 2012. Nonetheless, China's industrial products export theil index is 2.291 in 2012, and it is more than 2.270 in 1992. On the whole, China's export diversification decreases. Furthermore, in 2012 China's industrial products export within theil index is lower than in 1992, and China's industrial products export between theil index is higer, which shows that China's industrial products export diversification intensive margin is expanding 
and extensive margin is reducing. That is to say the distribution of China's industrial products export trade volume became more uniform and the kinds of export products become relatively less. Indeed, the kinds of China's industrial products export are 2448 in 2012 ,the number is less than 2579 in 1992. But it is not difficult to find that the kinds of China's industrial products export are still at a higher level. From the aspect of development, China's industrial products export diversification still has much more space to improve, especially in the aspect of industrial products export diversification intensive margin.

Table 117 countries' industrial products export theil index and the rank of export diversification

\begin{tabular}{|c|c|c|c|c|c|c|}
\hline \multirow{2}{*}{$\begin{array}{c}\text { Year } \\
\text { Country }\end{array}$} & \multicolumn{3}{|c|}{1992} & \multicolumn{3}{|c|}{2012} \\
\hline & $\begin{array}{c}\text { Export } \\
\text { theil } \\
\text { index }\end{array}$ & Rank & $\begin{array}{l}\text { Kinds of } \\
\text { export } \\
\text { product }\end{array}$ & $\begin{array}{c}\text { Export } \\
\text { theil index }\end{array}$ & Rank & $\begin{array}{c}\text { Kinds of } \\
\text { export } \\
\text { product }\end{array}$ \\
\hline Germany & 1.769 & 18 & 2666 & 2.0534 & 14 & 2436 \\
\hline Frances & 1.962 & 20 & 25940 & 2.294 & 78 & 2418 \\
\hline Netherlands & 2.0674 & 34 & 25944 & 2.206 & 4 & 24804 \\
\hline Italy & 2.0710 & 4 & 2631 & 2.07 & 24 & 2463 \\
\hline America & 2.091 & 54 & 2643 & 2.0769 & 34 & 2502 \\
\hline UK & 2.146 & 6.7 & 2568 & 2.52 & 10 & 2475 \\
\hline Spain & 2.236 & 74 & 2576 & 2.252 & 5 & 2461 \\
\hline Austria & 2.259 & 8 & 2448 & 2.395 & 8 & 2398 \\
\hline Chinas & 2.27 & 9 & 2579 & 2.2918 & 64 & 2448 \\
\hline Switzerland & 2.479 & 10,7 & 25334 & 3.723 & 17 & 2394 \\
\hline Hungary & 2.512 & 112 & 1758 & 3.116 & 16 & 22334 \\
\hline Japan & 2.529 & 120 & 2545 & 2.6714 & 120 & 2387 \\
\hline Denmark & 2.594 & 13 & 24944 & 2.599 & 11 & 2385 \\
\hline Poland & 2.776 .7 & 140 & 1606 & 2.47 & 9 & 2444 \\
\hline Mexicos & 2.802 & 15 & 2372 & 3.019 & 144 & 2405 \\
\hline Singapored & 2.917 & 160 & 2611 & 2.905 & 134 & 2424 \\
\hline Korea & 2.952 & 17 & 2365 & 3.098 & 15 & 23918 \\
\hline
\end{tabular}

\section{Conclusion and Enlightenment}

China's industrial products export diversification level is relatively high and China ranks top ten in 17 countries. The evolution of China's industrial products export diversification experiences extending, deepening, fluctuating and stability four stages. In extending stage, the change of export diversification extensive margin is very obvious. In deepening stage, the change of export diversification intensive margin is very obvious, but external demand shocks easily have influence on the fluctuation of export diversification intensive margin, which could impact on the stability of industrial products export diversification. China's export diversification extensive margin has a tendency of shrinkage by the track of China's industrial products export diversification and it changes stably, which means that it is limited to improve the level of China's industrial products export diversification by increasing the kinds of export products. If China wants to deepen its industrial products export diversification, it should increase industrial products export diversification intensive margin. That is to say China should positively explore foreign export market of existing industrial products under the condition of a little change of the scope of export products category, in order to increase China's industrial products export diversification intensive margin. Certainly, in order to prevent external demand shocks, China should make efforts to innovate and actively expand the category of industrial products exporting. China should ensure its industrial products export diversification to deepen and promote export diversification to extend. 
In a word, China's industrial products export diversification still has big development space. China should base on its own comparative advantages and encourage technological innovation to promote the development of China's industrial products export diversification extensive margin, meanwhile, China should pay attention to the transformation and upgrading of export structure; improve export products quality, and expand the markets of manufactured products to enhance China's industrial products export diversification intensive margin, and realize coordinated development of China's industrial products export diversification dual margin.

\section{Acknowledgements}

This paper is supported with the fund of Southeast Asia research center of Jiangxi Normal University.

\section{References}

1. Q. Xuefeng, X. Ping, The dual margin of China export growth and its determinants, J. Economic Research. Cssci. 1(2010) 65-79.

2. Y. Jingtao, W. Yunqiqike, Dual margins of China's export growth and their determinants, J. International Trade. Cssci.10(2013)53-64.

3. M. J .Melitz, The impact of trade on intra-industry reallocations and aggregate industry productivity, J.Econometrica. Ssci. 71(2003)1695-1725.

4. R. C.Feenstra, New product varieties and the measurement of international prices, J. The American Economic Review. Ssci. (1994) 157-177.

5. X. Xiangyun, An empirical analysis of China export variety's determinating factor- based on the dada of China's export to USA, J. Nanjing University of Finance and Economics. 6(2009) 19-24.

6. R. C. Feenstra, H. L. Kee, Trade liberalisation and export variety: a comparison of Mexico and China, J. The World Economy.Ssci.30(2007) 5-21.

7. O. Cadot, C. Carrere, V. Strauss-Kahn, Export diversification: what's behind the hump? J. The Review of Economics and Statistics.Ssci.93(2011)590-605.

8. S. Bin, Politic economic analysis of China's foreign trade policy. Publ., Shanghai, 2002, str.517-529. 